\title{
Bermain dan Belajar Pada Anak Usia Dini
}

\author{
Fitri Wahyuni \\ Institut Agama Islam Sunan Giri Ponorogo \\ wahyunif417@gmail.com \\ Suci Midsyahri Azizah \\ sucimidsyahri88@gmail.com \\ Institut Agama Islam Sunan Giri Ponorogo
}

\begin{abstract}
Abstrak
Anak usia dini memiliki cara yang unik dalam mempelajari sesuatu yang tentunya berbeda dengan orang dewasa. Seorang anak pada dasarnya tidak memahami bahwa yang dilakukannya saat bermain adalah sebuah kegiatan yang bagi orang tua dianggap sebagai kegiatan belajar. Bermain sambil belajar merupakan kegiatan yang dilakukan seorang anak usia dini yang dilakukan dengan perasaan senang, tanpa paksaan, namun memiliki pola-pola yang diharapkan mampu menciptakan hasil guna perkembangan baik bagi diri anak. Bermain juga merupakan sarana bagi anak guna menyalurkan energinya yang besar dan menemukan hal-hal baru yang sebelumnya belum diketahuinya dengan cara yang menyenangkan. Dan hal ini tentu berbeda dengan belajar yang dipahami orang dewasa dengan segala aturan dan tuntutan di akhirnya. Bermain (sambil belajar) pada anak usia dini mempunyai tujuan yang mungkin tidak disadari oleh orang dewasa, dimana saat anak bermain, sebenarnya ia sedang mengembangkan potensi yang terdapat dalam dirinya guna menjadi modal awal yang kokoh bagi dirinya di masa depan saat menghadapi permasalahan dalam hidup. Tulisan ini diharapkan memberikan referensi dan edukasi kepada orang tua dan guru paud khususnya untuk bisa memahami dunia anak usia dini salah satunya dengan memahami hakekat bermain dan makna bermain bagi anak usia dini. Hal ini diperoleh dengan mengesplorasi berbagai sumber dari beberapa literatur dari hasil penelitian dan pemikiran di mana hasilnya dapat digunakan bagi orang tua dan guru paud agar lebih tepat dalam mendampingi dan mendesain pembelajaran bagi anak usia dini sehingga mutiara pembelajaran paud yaitu bermain sambil belajar dapat tercapai.
\end{abstract}

Kata kunci: Bermain, Belajar, Anak usia dini

\begin{abstract}
Early childhood has a unique way of learning something that is certainly different from adults. A child does not understand that what he does while playing is an activity that for parents is considered a learning activity. Playing while learning is an activity carried out by a child at an early age carried out with feelings of pleasure, without coercion, but has patterns that are expected to be able to create results for good development for the child. Play is also a means for children to
\end{abstract}


channel their great energy and discover new things that they did not know in a fun way before. And this is certainly different from learning that is understood by adults with all the rules and demands in the end. Playing (while learning) in early childhood has goals that may not be realized by adults, where when children play he is developing the potential contained in him to become a strong initial capital for himself in the future when facing problems in life. This paper is expected to provide references and education to parents and parents especially to be able to understand the world of early childhood, one of them is by understanding the nature of play and the meaning of play for early childhood. This is obtained by exploring various sources of literature from the results of research and thinking where the results can be used for parents and paud teachers to be more precise in assisting and designing learning for young children so that pearls of paud learning, play while learning can be achieved.

Keywords: Play, Learn, Early childhood

\section{PENDAHULUAN}

Anak-anak menghabiskan begitu banyak waktu dan energi mereka seharihari dengan bermain sehingga para filsuf, peneliti, guru, dan orang tua sama-sama bertanya-tanya tentang peran permainan dalam perkembangan anak. Jelas, permainan harus memberikan manfaat fungsional dan evolusioner bagi anak yang sedang berkembang, sehingga perlu dikembangkan bagaimana sebuah permainan anak mampu menunjang mereka untuk berkembang lebih baik. Hal ini kemudian yang menjadi tugas pengajar di pendidikan anak usia dini harus terampil guna merumuskan permainan yang tetap menyenangkan namun mengedukasi anakanak.

Panduan untuk menciptakan permainan bagi Berdasarkan peraturan menteri pendidikan dan kebudayaan RI No 146 tahun 2014 tentang kurikulum 2013 PAUD, prinsip yang digunakan dalam proses pembelajaran PAUD adalah 'belajar sambil bermain' anak di bawah usia 6 tahun berada pada masa bermain, pemberian rangsangan pendidikan dengan cara yang tepat melalui bermain dapat memberikan pembelajaran yang bermakna pada anak. Berdasar hal tersebut, perlu kiranya dirumuskan sebuah cara agar dapat menyatukan antara bermain dan belajar yang terpat untuk anak usia dini. Bermain yang tidak hanya bermain dan belajar yang tidak membebani laiknya sedang bermain. 


\section{KARAKTER CARA BELAJAR ANAK}

Cara belajar anak berbeda dengan orang dewasa sehingga pembelajarannya pun harus dilakukan dengan strategi yang berbeda. Belajar bagi seorang anak mmemiliki karakteristik sendiri yang berbeda dengan orang dewasa, di antaranya yaitu bermain sambil belajar, belajar alamiah, dan membangun sendiri pengetahuannya. Groos ${ }^{1}$ telah memunculkan hipotesis bahwa salah satu fungsi penting dari permainan adalah berhubungan langsung dengan kemampuan pemecahan masalah, memberikan individu dengan keterampilan khusus untuk menyelesaikan berbagai masalah yang ditimbulkan dalam keadaan kehidupan lain. Bermain dianggap sebagai orientasi yang memberi individu kemampuan untuk menerapkan sebagian besar dari dirinya dimana pengalaman main-main dengan objek dan prosedur untuk masalah kehidupan nyata yang tidak muncul dalam situasi permainan asli. Hal ini sesuai dengan pandangan para ahli konstruktivisme mengenai belajar pada anak yang memunculkan kemampuan untuk membangun pengetahuannya dengan bermain melalui eksplorasi yang dilakukan terhadap objek yang ditemui dan interaksi yang dilakukannya. ${ }^{2}$

Ada dua pemikiran umum tentang bagaimana sebuah permainan dapat berkontribusi pada pengembangan kemampuan berpikir divergen. Pertama yaitu anggapan bahwa bermain merupakan kontribusi untuk perkembangan kemampuan berpikir berdasarkan sifatnya yang eksperimental dan fleksibel. Manfaat dari sifat eksperimental ini dalam bermain adalah memberikan repertoar luas kepada keterampilan dan tanggapan anak, dan dengan pendekatan yang fleksibel digunakan untuk menyelesaikan tugas secara efektif atau masalah pemikiran yang berbeda. Cara kedua melihat hubungan antara bermain dan kemampuan berpikir yang berbeda adalah dengan berfokus pada sifat simbolis, kepura-puraan yang menjadi ciri banyak permainan anak kecil. Hal ini telah dikemukakan oleh beberapa ahli, bahwa terdapat teori yaitu bahwa bermain berfungsi untuk

1 Lynn A. Barnett, "Developmental Benefits of Play for Children," Journal of Leisure Research 22, no. 2 (1990): 138-53, https://doi.org/10.1080/00222216.1990.11969821.

${ }^{2}$ Mulyasa, Strategi Pembelajaran PAUD (Bandung: PT. Remaja Rosdakarya, 2017), 57-58. 
memfasilitasi transisi anak dari proses pemikiran konkret ke abstrak (Vygotsky, 1967). ${ }^{3}$ Telah dikemukakan bahwa representasi simbolik itu begitu sering diproduksi dalam bentuk permainan yang merupakan bagian dari proses yang dilalui seorang anak dalam mengembangkan kemampuan untuk berpikir secara abstrak.

Seorang anak usia dini, pada umumnya, memiliki pandangan terhadap segala sesuatu sebagai hal yang utuh yang berwujud konkret dan langsung dirasakan dan dialami olehnya. Dengan demikian, cara belajar anak memiliki beberapa karakter khusus yang dapat diidentifikasi sebagai berikut. ${ }^{4}$

1. Belajar melalui gerakan reflek dan aktifitas tubuhnya.

2. Belajar memerankan perasaan dan hati nuraninya.

3. Belajar sambil bermain.

4. Belajar melalui komunikasi, interaksi, dan sosialisasi.

5. Belajar dari lingkungan.

6. Belajar memenuhi hasrat dan kebutuhan.

Berangkat dari hal-hal yang dimiliki anak, setiap pembelajaran harus memberikan kesempatan kepada anak sehubungan dengan cara dan kebiasaan anak usia dini sebagaimana diuraikan di atas. Proses pembelajaran yang akan dilakukan harus memenuhi prinsip-prinsip sebagai berikut:

1. Mulai dari yang konkret dan sederhana. Pembelajaran anak usia dini harus disesuaikan dengan masa perkembangannya dimana anak usia dini belum mampu menerima dan memahami sesuatu yang bersifat abstrak, sehingga cara menjelaskan dan memberikan pengertian haruslah nyata dan sederhana.

2. Untuk memperoleh pengalaman dan dan pengetahuan baru, tetapi tetap menghubungkan dengan hal-hal yang sudah dikenal oleh anak. Pengenalan dan pengakuan. Pengenalan dan pengakuan atas peran anak sangat penting dalam memunculkan inisiatif dan keterlibatan aktif anak dalam pembelajaran.

\footnotetext{
${ }^{3}$ Barnett, "Developmental Benefits of Play for Children.", 141.

${ }^{4}$ Mulyasa, Strategi Pembelajaran PAUD, 58-60.
} 
3. Menantang. Aktivitas pembelajaran yang dirancang harus menantang anak untuk mengembankan pemahaman sesuai dengan apa yang dialaminya. Bila anak mampu menyelesaikan tantangan pertama, maka dapat diberikan tantangan berikutnya yang lebih menantang lagi sehingga tidak membosankan.

4. Bermain dan permainan. Belajar melalui bermain dan permainan dapat memberi kesempatan kepada anak untuk bereksplorasi, berimprovisasi, berkreasi, mengekspresikan perasaan, dan belajar secara menyenangkan. Bermain juga dapat membantu anak mengenal diri dan lingkungannya.

5. Alam sebagai sumber belajar. Alam merupakan sumber belajar yang tak terbatas bagi anak untuk bereksplorasi dan berinteraksi dalam membangun pengetahuan dan pemahamannya. Rabbindranath Tagore menggunakan model pembelajarannya hamper 90\% kegiatannya dilakukan dengan berinteraksi dengan alam. Anak diajarkan dapat membangun ikatan emosional di antara teman-temannya, menciptakan kesenangan belajar, menjalin hubungan serta memengaruhi memori dan ingatan yang cukup lama akan bahan-bahan yang dipelajari.

6. Sensori. Pengetahuan apapun yang diperoleh anak-anak dari lingkungan yaitu melalui sensorinya. Baik itu merasakan, penciuman, pendengaran, maupun penglihatannya. Bagaimana perkembangan sensorinya akan berkembang dengan baik, yaitu dengan memberikan stimulus yang baik dan optimal kepada anak-anak tersebut.

7. Belajar membekali keterampilan hidup. Belajar harus dapat membekali anak untuk memiki ketrampilan hidup (life skill) sesuai dengan kemampuan masingmasing. Dengan demikian, anak belajar untuk memiliki kemandirian dan rasa tanggung jawab terhadap dirinya.

8. Fokus pada proses. Yang terpenting di sini adalah bagaimana anak-anak berproses dalam belajar. Fokus pada bagaimana anak-anak itu berproses pada belajar, bersosialisasi, dan berfikirnya. Suatu produk atau hasil merupakan hal untuk bahan evaluasi agar menjadi lebih baik.

Berdasarkan cara belajar dan proses yang harus disajikan pada anak usia dini, guru dapat mencipatkan kondisi dan lingkungan belajar yang baik, yang bisa 
menghadirkan pembelajaran yang optimal. Untuk itulah perlu dipilih sebuah strategi khusus dlam pembelajaran anak usia dini dimana cara prosesnya pun berbeda dengan jenjang pendidikan lainnya.

Pemilihan strategi pembelajaran PAUD perlu memperhatikan hakikat dan perkembangan anak usia dini, seperti yang diteliti oleh para ahli, antara lain oleh Bredecam dan Copple, Brener, serta Kellough sebagai berikut. ${ }^{5}$

1. Anak berkembang sesuai kemampuan masing-masing. Setiap anak mempunyai ciri khas sendiri-sendiri

2. Anak mengekspresikan perilakunya secara relatif spontan.

3. Anak merupakan individu yang berbas bergerak dan bebas berkreasi..

4. Anak itu egosentris.

5. Anak mempunyai sifat ingin tahu yang besar pada hal-hal yang baru.

6. Anak memiliki jiwa petualang yang kuat..

7. Anak mempunyai banyak imajinasi-imajinasi.

8. Anak masih mudah frustasi.

9. Anak masih kurang mempunyai perhitungan dalam melakukan sesuatu hal.

10. Anak memiliki daya perhatian yang pendek.

11. Anak mempunyai potensi yang sangat besar dalam hal belajarnya.

12. Anak makin menunjukkan minat terhadap teman.

Dalam menentukan strategi pembelajaran bagi Anak paud dibutuhkan guru yang memahami seluk beluk dan juga keilmuan paud, di antara keilmuan paud adalah memahami karakter anak usia dini, bagaimana cara belajarnya, bagaimana perkembangan sosial emosionalnya, bahasanya, kognitifnya sehingga seorang guru Paud dapat mengurangi kesalahan dalam mendesain sebuah pembelajaran paud.

\section{ARTI DAN MANFAAT BERMAIN BAGI ANAK}

Fungsi penting dari permainan adalah bahwa itu berhubungan langsung dengan kemampuan pemecahan masalah, memberikan individu dengan keterampilan khusus untuk memecahkan berbagai masalah yang ditimbulkan

${ }^{5}$ Ibid., $63-64$. 
dalam keadaan kehidupan lain. Bermain merupakan dunia anak dan masa anak untuk mengeksplorasikan semua yang ada pada anak. Permaianan pada anak adalah semua aktivitas yang dilakukan anak-anak baik berupa gerakan, fikiran maupun perkataan. Bermain berupa gerakan seperti: lari-larian, melompat, memanjat dan lain-lain. Bermain yang menggunakan fikiran seperti: bermain puzzle, menyusun balok mengingat lagu, mengingat dialog orang lain yang didengarkan. Bermain dengan perkataan adalah dengan cara anak-anak mengungkapkan perasaannya dengan kata-kata dan menirukan perkataan orang lain. Kesimpulan para ahli yaitu anak merupakan makhluk yang sangat kreatif dan dinamis. Kebutuhan anak hanyalah bermain baik yang dilakukan sendiri maupun dilakukan bersama-sama (kelompok). ${ }^{6}$

1. Arti bermain bagi anak

Dari hasil penelitian, pengamatan, dan pengalaman para ahli bahwa dengan bermain seorang anak akan mampu mengembangkan beberapa hal dalam dirinya, di antaranya:

a. Anak mempunyai peluang untuk berekspresi dan eksplorasi apa yang ada pada diri anak.

b. Minat bakat, kemampuan dan kelemahan akan muncul dan kelihatan pada diri seorang anak.

c. Anak berkesempatan untuk mengembangkan lima aspek perkemabngan anak usia dini yaitu fisik, motorik, bahasa, kognitif, dan moral agama.

d. Panca indera akan berkembang dengan baik karena ketika bermain anak menggunakan seluruh panca inderanya.

e. Menjadi motivasi untuk mengetahui sesuatu hal. ${ }^{7}$

Dalam mengimplementasikan arti bermain di taman kanak-kanak yang dapat dilakukan pertama kali yaitu dengan menggunakan metode pembelajaran yang asik dan menyenangkan. Seorang guru diharapkan bisa mengkondisikan

${ }^{6}$ B.E.F. Montolalu dkk. Bermain dan Permainan Anak (Tangerang Selatan: Universitas Terbuka, 2012), 1.2.

${ }^{7}$ Ibid., 1.3-1.5. 
kelas yang tidak monoton, anak-anak tetap senang, dan yang terpenting adalah anak-anak tidak merasa bahwa itu suatu pembelajaran yang harus diikuti. Pernyataan ini bisa diartikan bahwa di dalam pembelajaran anak-anak bermain akan tetapi di dalamnya mengandung suatu pembelajaran. Anak-anak diajak bereksplorasi dengan bebas, memanfaatkan objek yang ada di lingkungan sekitar, sehingga anak bisa menemukan sesuatu yang bermanfaat. Bermain pada pembelajaran di taman kanak-kanak akan menjadi bermakna karena sebagai berikut:

1. Bermain itu belajar

Aspek kognitif pada anak akan berkembang dengan baik dengan cara mengajaknya bermain dan bereksplorasi secara bebas di alam sekitar. Anak akan menemukan hal-hal yang baru baik dengan sesuatu ciptaan Tuhan maupun buatan manusia. Contoh kegiatan yang dapat dilakukan yaitu mengamati tanaman tumbuh, dimana anak meningkatkan pengetahuannya tentang bagiamana dan mengapa tanaman tumbuh, mengalami perubahan dan berfungsi (sebagai makanan). Dengan cara bermain ini anak-anak bisa membuka wawasan seluas-luasnya dan berkesempatan untuk mengamati halhal baru. Selain itu anak-anak akan semakin penasaran dan rasa keingintahuannya tinggi pada hal-hal baru. Rasa keingintahuannya ini akan berlanjut ke masa dewasanya kelak.

2. Bermain itu bergerak

Kegiatan yang ada di taman kanak-kanak yaitu bermain, akan merangsang perkembangan motorik kasar maupun motorik halusnya. Baik bermain dengan suatu alat maupun bermain dengan tidak menggunakan alat. Bermain untuk mengembangan motorik halus seperti bermain krayon, plastisin, gunting, mencocokkan gambar, dan lain sebagainya. Kegiatan ini menggunakan dan meningkatkan kinerja otot-otot halus. Untuk mengembangkan motorik kasar contohnya yaitu berlari, melompat, memanjat, menggelinding, dan sebagainya. Kegiatan ini menggunakan dan meningkatkan kinerja otot-otot besar pada anak dan memperkuat fisik anak. Selain itu, dengan melatih motorik kasarnya, anak akan siap menghadapi aktivitas- 
aktivitas sehari-hari di rumah dan di lingkungannya. Dan juga akan menumbuhkan rasa percaya diri pada anak akan kekuatan tubuhnya.

3. Bermain membentuk perilaku

Program kegiatan belajar di taman kanak-kanak dipadukan dengan program belajar yang utuh dalam rangka pembentukan perilaku melalui pembiasaan serta program dalam rangka pengembangan pengetahuan dasar. Di taman kana-kanak akan terus dilakukan pembiasaan-pembiasaan yang baik sehingga akan tercipta perilaku yang baik pula. Pembiasaan ini tidak terlepas dari kegiatan bermain anak. Pembentukan perilaku ini yaitu dengan cara mengembangakan lima aspek perkembnagan anak usia dini yaitu moral agama, sosial emosional, fisik motorik, kognitif dan bahasa. Pemerolehan bahasa juga menjadi salah satu aspek perkembangan yang menjadikan seorang anak akan tumbuh menjadi pribadi yang matang dan mandiri. ${ }^{8}$

Bermain pada usia dini bertujuan untuk menanamkan pekerti baik dan melatih berbagai hal di antaranya membedakan sikap dan perilaku yang baik dan yang tidak baik, bersikap ramah dan peduli, disiplin dan tanggung jawab, mencintai ciptaan Tuhan, tertib dan berani, serta untuk mengetahui baik dan buruk. Perlu waktu yang tidak sedikit untuk seorang anak dalam pengembangan dirinya. Dari penelitian beberapa ahli menyatakan bahwa bermain pada anak mempunyai peran yang sangat penting. Dengan bermain anak-anak bisa menyalurkan keinginan, kepuasan, kreativitas, dan imajinasinya. Selain itu dengan bermain anak-anak bisa melatih fisiknya, bergaul dengan teman sebaya, memainkan peran sesuai dengan jenis kelaminnya, mengembangkan bakatnya, menumbuhkan sifat dan sikap yang positif dan bisa mengekspresikan dan menyalurkan perasannya baik pearsaan tertekan, senang mapun sedih. ${ }^{9}$

Secara keseluruhan bermain bagi anak mempunyai manfaat yang besar, selain manfaat pada lima aspek perkembangan anak. Yaitu sebagai berikut:

\footnotetext{
${ }^{8}$ Rizki Amalia Sholihah, “Attitude, Aptitude, Routines, Pattern, Dan Simple Codes Dalam Pemerolehan Bahasa," Al-Adabiya: Jurnal Kebudayaan Dan Keagamaan 12, no. 2 (2017): 17184.

${ }^{9}$ B.E.F. Montolalu dkk,Bermain dan Permainan Anak, ... 1.18-1.22.
} 
1. Bermain memicu kreativitas

Permainan yang aman dan menyenangkan memicu anak untuk bermain dan menemukan ide-ide serta menggunakan daya khayalnya. Hasil penelitian mendukung dugaan bahwa bermain dan kreativitas saling berkaitan karena baik bermain maupun kreativitas mengandalkan kemampuan anak menggunakan simbol-simbol. ${ }^{10}$ Kreativitas dipandang sebagai sebuah aspek pemecahan masalah dari akar dasar dalam bermain. Di saat anak menggunakan daya khayalnya, entah itu dengan alat maupun tidak, kreativitas mereka lebih menonjol.

2. Bermain bermanfaat mencerdaskan otak

Bermain suatu media yang sangat crusial dalam proses berfikir anak. Perkembangan kognitif anak tidak bisa terlepas dari proses yang dinamakan dengan bermain. Rasa senang dalam bermain membantu perkembangan intelektual atau kecerdasan berfikir anak yang nantinya akan mendapat berbagai pengalaman, sehingga dapat memperkaya cara berfikir mereka.

3. Bermain bermanfaat menanggulangi konflik

Pada anak usia dini atau TK, tingkah laku yang sering muncul adalah tingkah laku kontra sosial, misalnya, egois, agresif, hiperaktif, bersaing, marah, meniru, bertengkar, dan mau menang sendiri. Tetapi harus dapat dimengerti tingkah tersebut tidak dapat dihindarkan, tingkah yang kontra sosial justru malah dibutuhkan kemunculannya untuk dapat mengarahkan anak pada sikap prososial. TK memberikan peluang besar bagi anak untuk pengarahanpengarahan ke dalam hal positif melalui bermain dalam konflik yang terjadi. Bermain sandiwara, drama bebas, dan cerita melalui berbagai metode adalah kegiatan yang dimaksudkan.

4. Bermain bermanfaat untuk melatih empati

Empati adalah suatu perasaan seseorang yang ikut merasakan apa yang dirasakan orang lain. Dengan mempunyai sifat empati anak akan pandai menempatkan dirinya pada keadaan orang lain, dan akan muncul sifat tenggang

10 Olivia N. Saracho and Bernard Spodek, "Children's Play and Early Childhood Education: Insights from History and Theory," Journal of Education 177, no. 3 (1995): 129-48, https://doi.org/10.1177/002205749517700308. 
rasa pada anak. Sifat empati ini adalah sifat yang menunjukkan jiwa sosial anak, sehingga bisa dikatakan bahwa sifat empati bisa mengembangkan aspek perkembangan anak usia dini yaitu sosial emosional. Contoh pengembangan sifat empati pada anak di taman kanak-kanak yaitu dengan metode bermain peran. Anak memerankan suatu peran tertentu dan cerita tertentu, maka anak tersebut bisa terbangun sifat-sifat yang ada dalam cerita tersebut.

5. Bermain Bermanfaat Mengasah Pancaindra

Panca indera seorang anak yaitu penglihatan, pedengaran, penciuman, peraba dan pengucapan harus di asah dan di stimulus dengan baik dari sejak bayi. Kenapa panca indera tersebut harus di stimulus dengan baik, karena ketika anak mempunya panca indera yang bagus maka anak tersebut akan cepat menyearap pembelajaran yang ada di sekolah. Contohnya, indera penglihatan dan pendengaran, apabila kedua indera tersebut berkembang dengan baik maka akan mudah manangkap apa yang diperintahkan guru, akan mudah menyerap apa yang diajarkan guru di taman kanak-kanak. Selain itu anak juga gampang peka terhadap apa yang terjadi lingkungan sekitarnya. Banyak metode pembelajaran di taman kanak-kanak yang bisa mengasah panca indera secara optimal, sehingga perkembangan kepekaan panca indera akan berkembang secara baik. Seperti permainan "kotak aroma" untuk latihan indra pencium, permaian "suara apa" untuk latihan indra pendengar, gambar-gambar di buku untuk latihan indra penglihatan, nyanyian "apa rasanya" dan permaninan merasakan berbagai rasa makanan dengan mata tertutup untuk melatih indra pengecapan, dan banyak lagi.

6. Bermain sebagai media terapi (pengobatan)

Permainan merupakan salah satu cara untuk pemecahan konflik dan mengatasi kecemasan yang terjadi pada anak. Ini dikemukakan oleh bapak psikoanalisis, Sigmun Freud, yaitu permainan bisa dijadikan sebuah terapi, disebut sebagai terapi bermain. Terapi bermain dijadikan alat diagnosis bagi anak-anak yang mempunyai masalah yang harus dipecahkan. Akan tetapi terapi ini tidak semua orang bisa melakukannya karena harus melalui pelatihan dan pendidikan khusus. 
7. Bermain itu melakukan penemuan

Dengan bermain anak akan menemukan hal-hal baru yang mungkin sebelumnya belum pernah dia temui. Anak selalu ingin tahu dan selalu bertanya ketika ada sesuatu hal yang belum mereka fahami saat bermain. Sehingga seorang guru harus membebaskan anak untuk bermain dan bereksplorasi sepuasnya dengan tetap mengkontrolnya.

\section{BENTUK-BENTUK PERMAINAN ANAK}

Ada tiga bentuk permainan, yang pertama adalah eksploratif, kedua konstruktif, dan ketiga adalah bermain pura-pura. Eksploratif adalah permainan dengan cara mengerak-gerakan suatu benda dengan tujuan tertentu. Permainan konstruktif adalah permainan yang menggunakan suatu benda dan menyusunnya menjadi suatu barang tertentu seperti rumah-rumahan, menara, gedung, dan sebagainya. Permainan pura-pura adalah permainan dengan cara menirukan gaya orang lain atau memerankan peran orang lain. Bermain pura-pura ini sangat bermanfaat bagi anak yaitu mengatasi suatu konflik dan kecemasan yang berasal dari teori psikoanalitik.

Selain itu dari pendapat para pakar bahwa ada beberapa bentuk permainan anak yaitu $^{11}$ :

1. Bermain sosial

Beberapa jenis kegiatan bermain untuk anak bisa bersifat soliter (bermain seorang diri), sebagai penonton, bermain paralel, bermain asosiatif, dan bermain bersama.

a. Bermain seorang diri

Dalam permainan ini, anak bermain mandiri tanpa menghiraukan apa yang terjadi di sekitarnya atau apa yang dilakukan anak lain di dekatnya. Contoh permainan ini menyusun balok menjadi sebuah menara atau permainan bongkar pasang.

b. Bermain sebagai penonton

${ }^{11}$ Mansur, Pendidikan Anak Usia Dini Dalam Islam (Yogyakarta: Pustaka Pelajar, 2005), 155-158. 
Posisi anak sedang bermain secara mandiri namun melihat pergerakan permainan yang dilakukan anak lain yang berada pada tempat yang sama. Mungkin setelah melihat permainan temannya, anak melakukan permainan itu sendiri. Anak yang bermain sebagai penonton sudah pasti dia dalam posisi pasif sedangkan anak yang lain aktif bermain, namun tetap memperhatikan dengan seksama terhadap apa yang terjadi di sekitarnya.

c. Bermain paralel

Adalah suatu permainan yang dilakukan oleh beberapa anak dengan menggunakan alat permainan yang sama, namun anak-anak bermain secara mandiri, sehingga apa yang dilakukan tidak ada saling ketergantungan atau tidak tergantung antara satu sama lain. Biasanya saling berbicara antara satu sama lain namun jika salah satu meninggalkan permainan, kegiatan bermain tetap berlanjut.

d. Bermain asosiatif

Permainan ini adalah dimana anak bermain bersama tetapi tidak ada suatu pengaturan, beberapa anak mungkin memilih menjadi polisi dan yang lainnya memilih menjadi penjahat sehingga terjadi kegiatan permainan kejar-kejaran. Dimungkinkan juga permainan petak umpet, satu anak menghitung disebut dengan penjaga hingga sekian sesuai kesepakatan dan yang lainnya berlari untuk sembunyi kemudian setelah hitungan selesai penjaga mencari teman yang lain untuk yang pertama kali tertangkap menjadi penjaga berikutnya.

\section{e. Bermain kooperatif}

Dalam permainan ini, anak memiliki peran masing-masing sehingga tujuan permainan bisa tercapai. Misalnya anak bermain dokter-dokteran, ada dokter, perawat, pasien, dan keluarga pasien. Jika salah satu tidak mau untuk berperan pada salah satu tokoh kemungkinan besar permainan ini batal dilakukan. Anak-anak dengan berbagai usia akan menunjukkan tahapan perkembangan sosial bermain berbeda-beda. Kognitif anak yang masih sangat muda tidak dapat menerima berbagai peran dalam bermain kooperatif. Disebabkan belum memperoleh informasi yang luas terhadap 
seni berperan atau belum memiliki keterampilan sosial dalam permainan kelompok.

f. Bermain dengan benda

Ada tiga bentuk bermain dengan benda. Yang pertama adalah bermain praktis, kedua bermain simbolik, dan yang ketiga adalah bermain dengan peraturan.

Bermain praktis adalah bermain yang dilakukan oleh anaknya langsung, yaitu anak bermain dengan cara memainkan suatu benda. Anak bebas mengeksplorasikan benda tersebut untuk dijadikan beberapa kemungkinan permainan. Contohnya, anak bermain batu. Batu tersebut dibuat seorang anak menjadi pagar-pagaran rumah.

Bermian simbolik adalah bermain dimana anak menggunakan imajinasinya dalam suatu permainan. Contohnya, seorang anak bermain lego. Lego tersebut dijadikan sebuah rumah-rumahan, gedung yang tinggi, menara, dan lain sebagainya. Di sini anak berimajinasi seolah-olah anak tersebut adalah seorang kontraktor yang membangun sebuah proyek.

Bermain dengan perturan adalah bermain dengan cara menggunakan aturan-aturan yang harus dipatuhi. Permainan ini bisa diterapkan tergantung kematangan anak dalam memahami peraturan. Apabila anak semakin matang dan faham akan peraturan ini maka anak semakin lihai dalam memainkan permainan benda, dengan hasil yang simbolik dengan aturanaturan yang ada.

2. Bermain Sosio-Dramatik

Ada beberapa elemen dalam permainan Sosio-dramatik, yaitu:

a. Bermain peran, yaitu menirukan kegiatan atau percakapan antara guru dengan murid.

b. Persisten, kegiatan bermain selama minimal sepuluh menit dengan tekun dan seksama.

c. Interaksi, adegan yang dilakukan minimal dua anak. 
d. Komunikasi verbal, setiap kegiatan bermain ada komunikasi verbal di antara anak.

e. Imitasi, anak pura-pura melakukan peran orang di sekitarnya baik pembicaraan ataupun tingkah laku.

f. Pura-pura sebagai suatu objek, anak melakukan sesuatu layaknya objek tersebut baik gerakan maupun suaranya, misalnya anak pura-pura sebagai sepeda motor, anak berlari melenggang layaknya sepeda motor yang sedang melaju.

Bermain sosio-dramatik sangat membantu dalam perkembangan kreativitas, intelektual, serta keterampilan sosial anak. Tetapi harus dipahami tidak semua anak mengalami bermain sosio-dramatik. Maka dari itu, para guru harus memberikan pengalaman bermain sosio-dramatik. Bermain sosio-dramatik atau yang lebih familier bermain peran sangat bagus diterapkan pada anak usia Paud, guna merangsang daya kreativitas serta keterampilan sosial anak, tentunya dengan variasi, kreasi, dan desain pembelajaran anak usia dini.

\section{SYARAT-SYARAT BERMAIN DAN PERMAINAN EDUKATIF ANAK USIA DINI}

Dalam bermain dan permainan edukatif anak usia dini ada lima syarat, yaitu ${ }^{12}$ :

\section{Play time}

Masa usia dini adalah masa bermain, bukan masa belajar yang dipaksakan. Maka dari itu, pebelajaran anak adalah permainan yang mendidik dengan memperhatikan antara waktu dan jenis permainan. Permainan di luar ruang seyogyanya dilakukan pada pagi hari atau sore hari, agar anak tidak kepanasan sehingga mereka merasa nyaman.

\section{Play Things}

Alat permainan harus disesuaikan dengan usia dan taraf perkembangan anak.

Alat permainan harus memenuhi kriteria sebagai berikut:

\footnotetext{
${ }^{12}$ Herman, Rusmayadi, dan I Waya Utama, Sumber Belajar Penunjang PLPG 2017 Materi Profesional Guru Kelas PAUD/TK (Kementerian Pendidikan dan Kebudayaan Direktorat Jenderal Guru dan Tenaga Kependidikan, 2017), 10-12.
} 
a. Aman.

b. Ukuran bentuk dan warna sesuai dengan usia dan taraf perkembangannya.

c. Berfungsi mengembangkan seluruh aspek perkembangan anak.

d. Dapat dimainkan secara bervariasi.

e. Merangsang partisipasi aktif anak.

f. Sesuai dengan kemampuan anak.

g. Menarik dari segi warna bentuk dan suara.

h. Tidak mudah rusak.

i. Mudah didapat dan terdapat di lingkungan anak.

j. Diterima oleh semua budaya.

Menurut Fitzhugh Dodson 90\% aktivitas anak dan 10\% adalah aktivitas alat permainan. Jadi, jumlah alat permainan hendaknya cukup dengan kebutuhan anak.

\section{Play Fellowes}

Anak harus merasa yakin bahwa ia memiliki teman bermain jika ia memerlukan. Namun juga harus proporsional, artinya jangan terlalu banyak bermain dengan anak lain atau banyak bermain dengan orang tua, ia harus memiliki kesempatan yang cukup untuk menhibur dirinya sendiri dan menemukan kebutuhannya sendiri.

\section{Play Space}

Lokasi bermain anak disediakan ruang yang cukup luas, sehingga anak bisa bermain dan bergerak secara bebas. Luas area bermain disesuaikan dengan jenis permainan dan jumlah anak yang sedang bermain.

\section{Play Rullesn}

Bermain dengan cara ini adalah yang terbaik. Dalam permainan ini anak mencoba sendiri, meniru, atau diberitahukan caranya, sehingga anak tidak terbatas pengetahuannya dalam menggunakan alat permainan. Jadi permainan 
yang baik adalah permainan yang memuat aturan permainan, dengan begitu kreativitas serta intelektual anak dapat terasah dengan cepat.

\section{PENUTUP}

Bermain sambil belajar merupakan kegiatan yang dilakukan orang seorang anak di usia dini yang dilakukan dengan perasaan senang, tanpa paksaan, namun memiliki pola-pola yang diharapkan mampu menciptakan hasil guna perkembangan baik bagi diri anak. Bermain juga merupakan sarana bagi anak guna menyalurkan energinya yang besar dan menemukan hal-hal baru yang sebelumnya belum diketahuinya dengan cara yang menyenangkan. Dan hal ini tentu berbeda dengan belajar yang dipahami orang dewasa dengan segala aturan dan tuntutan di akhirnya. Bermain (sambil belajar) pada anak usia dini mempunyai tujuan yang mungkin tidak disadari oleh orang dewasa, dimana saat anak bermain, sebenarnya ia sedang mengembangkan potensi yang terdapat dalam dirinya guna menjadi modal awal yang kokoh bagi dirinya di masa depan saat menghadapi permasalahan dalam hidup. Tulisan ini diharapkan memberikan referensi dan edukasi kepada orang tua dan guru paud khususnya untuk bisa memahami dunia anak usia dini salah satunya dengan memahami hakekat bermain dan makna bermain bagi anak usia dini. Hal ini diperoleh dengan mengesplorasi berbagai sumber dari beberapa literatur dari hasil penelitian dan pemikiran di mana hasilnya dapat digunakan bagi orang tua dan guru paud agar lebih tepat dalam mendampingi dan mendesain pembelajaran bagi anak usia dini sehingga mutiara pembelajaran paud yaitu bermain sambil belajar dapat tercapai.

\section{DAFTAR RUJUKAN}

Herman, Rusmayadi, dan I Waya Utama, Sumber Belajar Penunjang PLPG 2017 Materi Profesional Guru Kelas PAUD/TK. Kementerian Pendidikan dan Kebudayaan Direktorat Jenderal Guru dan Tenaga Kependidikan, 2017.

Mansur, Pendidikan Anak Usia Dini dalam Islam. Yogyakarta: Pustaka Pelajar, 2005.

Mulyasa. Strategi Pembelajaran PAUD. Bandung: PT. Remaja Rosdakarya, 2017. 
Montolalu, B.E.F. dkk. Bermain dan Permainan Anak. Tangerang Selatan: Universitas Terbuka, 2012.

Barnett, Lynn A. "Developmental Benefits of Play for Children." Journal of Leisure Research 22, no. 2 (1990): 138-53. https://doi.org/10.1080/00222216.1990.11969821.

Saracho, Olivia N., and Bernard Spodek. "Children's Play and Early Childhood Education: Insights from History and Theory." Journal of Education 177, no. 3 (1995): 129-48. https://doi.org/10.1177/002205749517700308.

Sholihah, Rizki Amalia. “Attitude, Aptitude, Routines, Pattern, Dan Simple Codes Dalam Pemerolehan Bahasa." Al-Adabiya: Jurnal Kebudayaan Dan Keagamaan 12, no. 2 (2017): 171-84. 